\title{
Continental shelf residency by adult Atlantic halibut electronic tagged in the Gulf of Maine
}

\author{
Andrew C. Seitz \\ College of Fisheries and Ocean Sciences, University of Alaska Fairbanks, P.O. Box 757220, \\ Fairbanks, AK 99775-7220 \\ acseitz@alaska.edu \\ Tel.: +1 907-474-5254 (voice); 907-474-7204 (fax) \\ Mark D. Evans \\ College of Fisheries and Ocean Sciences, University of Alaska Fairbanks, P.O. Box 757220, \\ Fairbanks, AK 99775-7220 \\ mdevans@alaska.edu \\ Tel.: +1 907-474-7202 (voice) \\ Michael B. Courtney \\ College of Fisheries and Ocean Sciences, University of Alaska Fairbanks, P.O. Box 757220, \\ Fairbanks, AK 99775-7220 \\ mbcourtney@alaska.edu \\ Tel.: +1 907-474-7202 (voice) \\ J. Kohl Kanwit \\ Bureau of Public Health, Maine Department of Marine Resources, P.O. Box 8, \\ West Boothbay Harbor, ME 04575-0008 \\ kohl.kanwit@maine.gov \\ Tel.: +1 207-633-9535 (voice)
}

SEITZ, A. C., M. D. EVANS, M. B. COURTNEY, and J. K. KANWIT. 2016. Continental shelf residency by adult Atlantic halibut electronic tagged in the Gulf of Maine. J. Northw. Atl. Fish. Sci., 48: 33-40. doi:10.2960/J.v48.m713

\begin{abstract}
In the Northwest Atlantic, emerging evidence suggests that different stocks of Atlantic halibut (Hippoglossus hippoglossus) exist in Canadian and U.S. waters. To examine the movement of Atlantic halibut that occupy the Gulf of Maine in U.S. waters during the summer, two types of electronic tags were attached to large adult fish $(n=70)$ in 2007-2009. None of the recovered tags $(n=12)$ provided evidence that the fish occupied the relatively deep waters of the continental slope during the winter, where Canadian Atlantic halibut have been shown to spawn. This observation provides additional evidence for the hypothesis that different stocks of Atlantic halibut exist in Canadian and U.S. waters. Furthermore, this observation requires reexamination of the long-standing assumptions made by fisheries scientists that all Atlantic halibut spawn in deep water on the continental slope and that the majority of mature Atlantic halibut spawn annually. This information may be important for understanding the population dynamics of Atlantic halibut in U.S. waters.
\end{abstract}

Keywords: Atlantic halibut, Hippoglossus hippoglossus, PSAT, satellite tag, electronic tag, Data Storage Tag, Gulf of Maine

\section{Introduction}

Atlantic halibut (Hippoglossus hippoglossus) is the largest and longest-lived of the flatfishes, and its range extends across the entire North Atlantic Ocean. In the Northwest Atlantic, the species is found from as far south as the coast of Massachusetts to as far north as the Canadian Arctic Ocean. The Gulf of Maine (GOM; Fig. 1) has a long history of commercial harvest of this species and it was found there in such abundance prior to the $1830 \mathrm{~s}$ that it was killed and discarded by Atlantic cod (Gadus morhua) fishermen who considered Atlantic halibut to be a nuisance (Grasso 2008). By 1880, its large size, tasty flesh and suitability to ice preservation had motivated such aggressive overfishing that the species was quickly driven to commercial extinction by the 1940s (Grasso 2008). 
Currently, the Atlantic halibut in the Northwest Atlantic is classified as a 'Species of Concern' in U.S. waters by National Marine Fisheries Service, 'threatened' by the American Fisheries Society and 'endangered' by the International Union for Conservation of Nature (NMFS 2009). Because recent stock assessments indicate that the Atlantic halibut in U.S. waters remains in a depleted state, there are only limited, size-restricted fisheries there (NEFSC 2012). However, Atlantic halibut abundance just across the Hague Line (the maritime border between the U.S. and Canada; Fig. 1) in Canadian waters on the Scotian Shelf and Grand Banks has rebounded, with high production and recruitment in recent years (Trzcinski and Bowen 2016). Today, Atlantic halibut from these Canadian waters are certified as sustainable by the Marine Stewardship Council (www.msc.org). Effective fisheries management plans, favorable ocean conditions, and reduced bycatch in other fisheries have all been speculated to be responsible for the recovery of the Canadian Atlantic halibut fishery (Trzcinski and Bowen 2016).

In the past, Atlantic halibut from the Northwest Atlantic in both Canadian and U.S. waters were assumed to come from a large, interbreeding stock (Stobo et al.

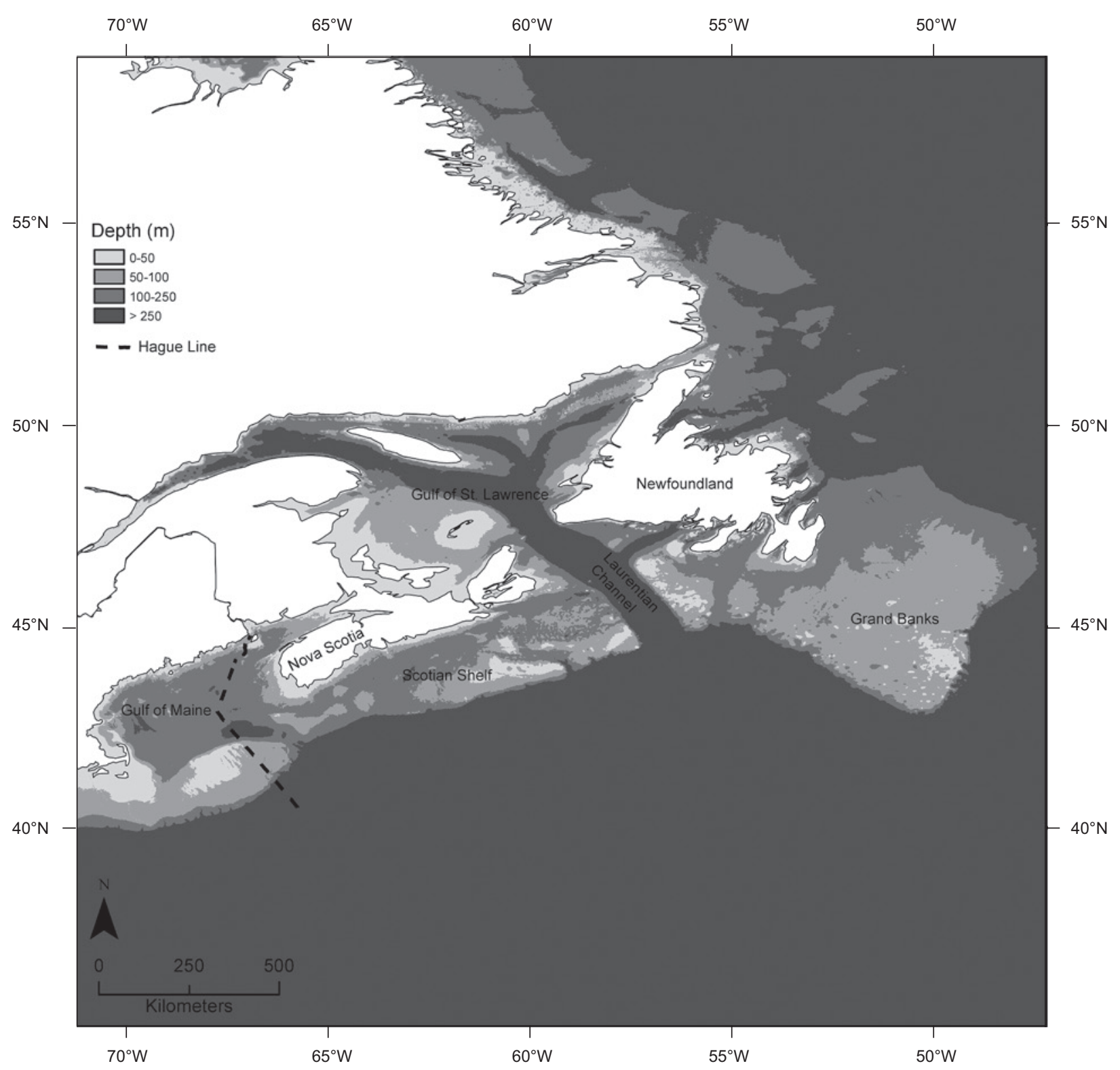

Fig. 1. Select areas and sea floor features in the northwest Atlantic occupied by Atlantic halibut. 
1988). However, there is much uncertainty surrounding Atlantic halibut stock identity and structure (NEFSC 2012; Shackell et al. 2016; Trzcinski and Bowen. 2016), and several lines of evidence suggest that Atlantic halibut may have finer stock structure than originally assumed (Shackell et al. 2016). First, recent research has documented large differences in abundances of juvenile Atlantic halibut from U.S. and Canadian waters (19652014), despite there not being any detectible shortage of suitable rearing habitat in either area (Shackell et al. 2016). Second, while Atlantic halibut have been shown to make extensive migrations $>3000 \mathrm{~km}$, the majority of fish are thought to remain near $(<50 \mathrm{~km})$ their respective release sites (Kanwit 2007; den Heyer et al. 2012). This observation indicates that relatively long movements of a minority of fish, which tend to attract researchers' attention, masks the overall tendency for individual Atlantic halibut to reside in relatively small areas. Third, while genetic analyses have found no significant genetic differentiation among Atlantic halibut from the GOM, Scotian Shelf, Gulf of St. Lawrence and Iceland (Reid et al. 2005), recent research demonstrates difficulty in detecting genetic differences between stocks of marine fishes (Hauser and Carvalho 2008). These results provide evidence for the hypothesis that different stocks of Atlantic halibut exist in U.S. and Canadian waters (Shakell et al. 2016). If different stocks of Atlantic halibut exist, this may explain why U.S. Atlantic halibut populations have not recovered (Shakell et al. 2016) while geographically proximate Canadian populations have rebounded.

Additionally, little is known about the reproductive biology and behavior of Atlantic halibut. The species is iteroparous and is assumed to spawn annually upon reaching maturity (Neilson et al. 1993). Atlantic halibut are generally thought to follow the distribution patterns of their congeners Pacific halibut (Hippoglossus stenolepis), spending summer months in relatively shallow, near-shore waters to feed and, in the winter, moving into deeper water on the continental slope, where spawning is presumed to occur (Stobo et al. 1988; Sigourney et al. 2006, Kanwit 2007; Armsworthy et al. 2014). As group-synchronous batch spawners, Atlantic halibut from several summer feeding areas are thought to gather in large spawning aggregations at discrete deep water locations (Bowering 1986; Haug 1990). In the Northwest Atlantic, documented spawning areas are located offshore along the continental slope in depths $>300 \mathrm{~m}$, including the Scotian Shelf (Fig. 1; Stobo et al. 1988); on the southern flank of the Grand Banks (Fig. 1; Armsworthy et al. 2014); and on the continental slope off western Greenland (Godø and Haug 1988). In the Northeastern Atlantic, some Atlantic halibut spawning areas have been identified at inshore locations, in Norwegian fjords (Devold 1938; Van Der Meeren et al. 2013), in depths $>800 \mathrm{~m}$, therefore, it is assumed that depth is an important habitat characteristic of spawning Atlantic halibut. The spawning season for Atlantic halibut in the Northwest Atlantic is a matter of some debate, but is thought to occur between late fall and spring, primarily from February to April in the Gulf of St. Lawrence (Fig. 1; Kohler 1967) and GOM (Fig. 1; Bigelow and Schroeder 1953; McCracken 1958), and November and December off the Scotian and Newfoundland coasts (Fig. 1; Neilson et al. 1993; Sigourney et al. 2006; Armsworthy et al. 2014).

In general, the goal of this study was to investigate stock identity, reproductive biology and behavior of Atlantic halibut in the Northwest Atlantic. To accomplish this, researchers from the Maine Department of Marine Resources conducted a multi-faceted, multi-year survey and tagging project in the GOM, part of which included attaching two types of electronic archival tags to Atlantic halibut during the summer. These tags measured and recorded environmental data at preprogrammed intervals while attached to the fish. In this paper, information obtained by the electronic tagging portion of the project was used to explore the hypothesis that Atlantic halibut in U.S. waters in the GOM do not intermingle with those from Canadian waters, and may comprise a distinct stock.

\section{Methods}

The Atlantic halibut tagged in this study were captured on longline gear at 65 stations along random grid transects of Maine's near-shore waters in 2007, 2008 and 2009 (Fig. 2 and Table 1). All of the tagged fish were weighed and measured, tagged quickly without anesthetic, and gently released head-first back into the ocean.

Sixty one Data Storage Tags (DST; Star Oddi, milli-TD, Gardabaer, Iceland) were externally attached to fish ranging in total length (TL) from 51 to $142 \mathrm{~cm}$. Each tag was attached to the eyed side of the fish with stainless steel wires inserted through muscle tissue along the dorsal fin and secured to a plastic backing plate on the white side of the fish. The DSTs measured and recorded ambient water temperature and water pressure, which was converted to depth, at intervals ranging from every five minutes to every 24 hours. The recording interval and battery life determined for how long the tags collected data. The data from these tags were recovered only after the fish was recaptured in fisheries.

Nine Pop-up Satellite Archival Tags (PSATs; X-tag, Microwave Telemetry, Inc., Maryland, USA) were also 


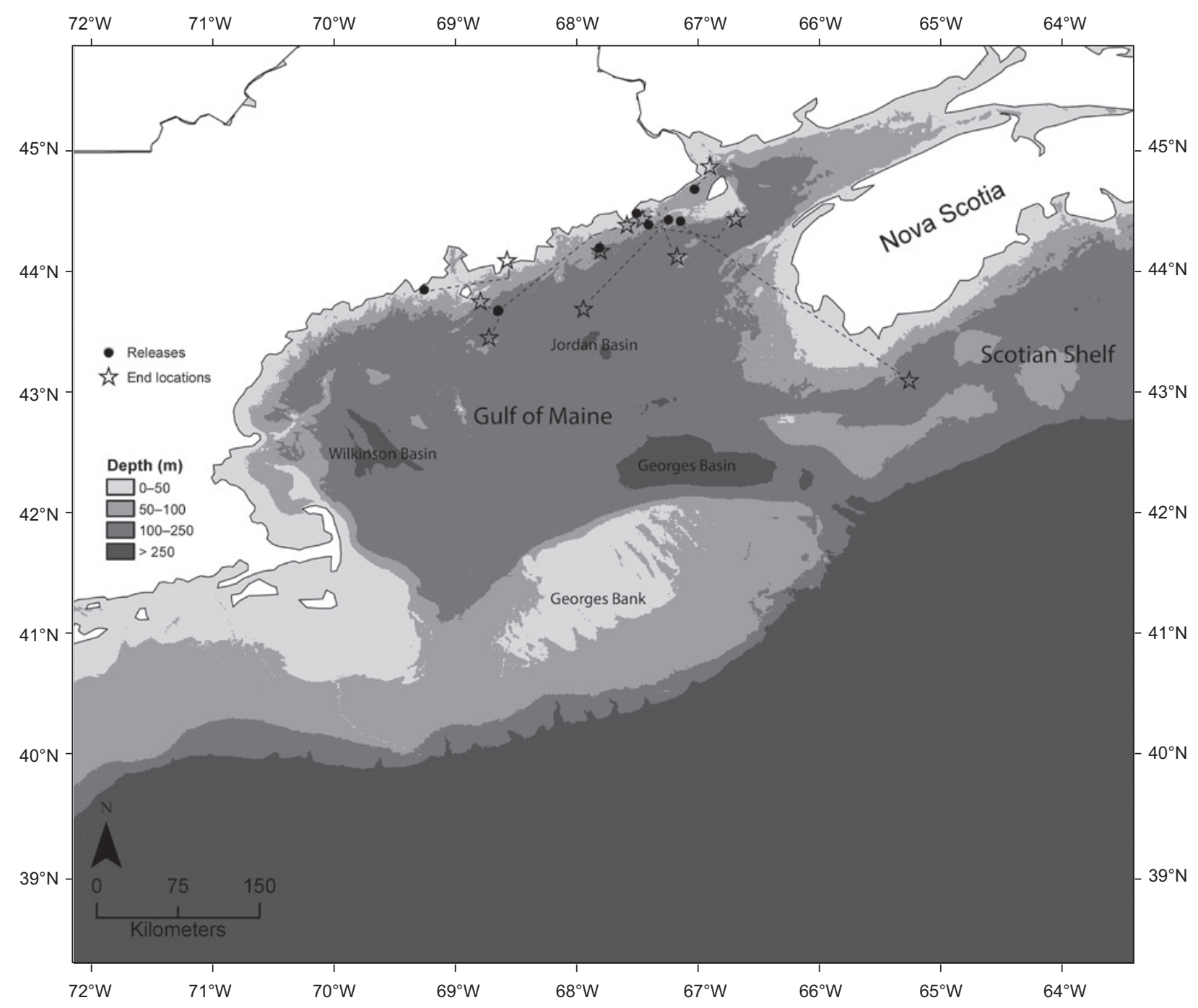

Fig. 2. Release (circles) and end locations (stars) of Atlantic halibut tagged with two types of electronic tags in the Gulf of Maine. End locations were considered as the Global Positioning System location where the fish was recaptured or the first message from Pop-up Satellite Archival Tags with an Argos Location Class 1, 2, or 3, resulting in a positional error of $<1.5 \mathrm{~km}$. Dashed lines are stylized paths traveled by each fish between release and end locations. The darkest gray shade denotes depths $(>250 \mathrm{~m})$ that none of the tagged Atlantic halibut occupied.

deployed. The fish selected for PSATs were generally larger, ranging from 92 to $148 \mathrm{~cm}$ (TL). These tags were attached to the fish with a tethered umbrella dart inserted through muscle tissue alongside the dorsal fin on the eyed side of the fish, in a location where the antenna would not interfere with the caudal fin during swimming. As with the DSTs, tagging was accomplished quickly and without anesthetic. These tags collected the same data as the DSTs, but had the additional benefit of being fisheries independent. Specifically, PSATs detached from a fish on a specified date, floated to the sea surface, and transmitted data to orbiting satellites (Argos satellite system). While transmitting to satellites, each tag's location was determined from the Doppler shift of successive transmissions to the passing satellite (Keating 1995). PSAT pop-up dates were staggered to provide different windows of time in which to view fish locations and occupied depths and temperatures. As such, some tags were scheduled to transmit data during the summer feeding season, while others were set to pop-up during the spawning season, purported to occur from November to January on the Grand Banks and Scotian Shelf (Neilson et al. 1993; Armsworthy et al. 2014). Still others were set to collect data for a full year. Because the satellites are limited in their ability to receive incoming data, data were sub-sampled by an onboard algorithm and then transmitted 
to satellites, resulting in temporal resolution of varying intervals, ranging from every four minutes to every 60 minutes, depending on deployment duration.

For all fish, end locations were considered as the Global Positioning System location where the fish was recaptured (for DSTs or PSATs that were physically recovered) or the first message from PSATs with an Argos Location Class 1,2 , or 3 , resulting in a positional error of $<1.5 \mathrm{~km}$.. Horizontal displacement of each fish was measured as the great-circle distance between each fish's tagging and end locations, and represents the minimum distance each fish could have traveled during its time at liberty with the tag. Assuming that Atlantic halibut are demersal and they occupy the seafloor at least once a day, maximum daily depths were used to infer approximate locations for the tagged fish. Specifically, if maximum daily depths were $<\sim 250 \mathrm{~m}$, a tagged fish was assumed to occupy the continental shelf while if maximum daily depths were $>\sim 250 \mathrm{~m}$, a tagged fish was assumed to occupy either the continental slope or a deep basin in the GOM. This coarse geoposition approximation does not provide accurate locations; however, more importantly in the context of this study, it provides information on where the fish could not have been.
The depth time series data were examined qualitatively for evidence of spawning activity. The spawning behavior of many flatfish species is characterized by a series of abrupt vertical ascents and descents in the water column, termed 'spawning rises'. In Atlantic and Pacific halibut, the 'spawning rises' are typically 100-200 $\mathrm{m}$ in amplitude, a range that presumably allows the fish to release its neutrally buoyant eggs at the most advantageous depth for survival of progeny. These rises are followed by a resting period on the seafloor that approximately corresponds to the ovulatory interval necessary to hydrate another batch of eggs (Seitz et al. 2005). This behavior has been attributed to both Pacific halibut (Seitz et al. 2005; Loher and Seitz 2008) and Atlantic halibut (Armsworthy et al. 2014), always occurring on the continental slope from depths $>400 \mathrm{~m}$ in the Pacific Ocean and $>800 \mathrm{~m}$ in the Atlantic Ocean.

\section{Results and Discussion}

Data were recovered from seven DSTs and five PSATs (Table 1), with measurement intervals ranging from every four minutes to every 90 minutes. Time at-liberty of individuals ranged from just two weeks (Tag 34260, 14 days) to almost two years (Tag 8833, 709 days), while

Table 1. Electronic tagging information for 12 Atlantic halibut from the Gulf of Maine in the Northwest Atlantic. Tag 8808 was physically recaptured and subsequently redeployed on another fish (8808B). Recovery date is when tags were physically recaptured or reported to Argos satellites. DST is Data Storage Tag, PSAT is Pop-up Satellite Archival Tag. Tag resolution is the frequency of depth data provided by each tag. The unknown (UNK) horizontal displacement could not be calculated because the end location of the tag was not provided. The discrepancy between a fish's time at-liberty and days of data of its corresponding tag resulted from the memory of the tag reaching its capacity before the tag was recaptured.

\begin{tabular}{|c|c|c|c|c|c|c|c|c|c|}
\hline Tag \# & $\begin{array}{l}\text { Tag } \\
\text { type }\end{array}$ & $\begin{array}{c}\text { Tag } \\
\text { resolution } \\
\text { (minutes) }\end{array}$ & $\begin{array}{l}\text { Total } \\
\text { length } \\
(\mathrm{cm})\end{array}$ & Tagging date & $\begin{array}{c}\text { Recovery } \\
\text { date }\end{array}$ & $\begin{array}{c}\text { Days } \\
\text { at-liberty }\end{array}$ & $\begin{array}{l}\text { Days } \\
\text { of data }\end{array}$ & $\begin{array}{l}\text { Horizontal } \\
\text { displacement } \\
\quad(\mathrm{km})\end{array}$ & $\begin{array}{r}\text { Max } \\
\text { depth } \\
\text { (m) }\end{array}$ \\
\hline 8808 & DST & 5 & 99 & $25 / 06 / 2007$ & $10 / 09 / 2008$ & 443 & 42 & 24 & 138 \\
\hline 8823 & DST & 5 & 142 & 02/07/2007 & $17 / 10 / 2007$ & 107 & 57 & 211 & 189 \\
\hline 8831 & DST & 5 & 113 & $12 / 06 / 2007$ & $24 / 11 / 2008$ & 531 & 72 & UNK & 207 \\
\hline 8833 & DST & 5 & 107 & $12 / 06 / 2007$ & $21 / 05 / 2009$ & 709 & 72 & 17 & 192 \\
\hline 9508 & DST & 60 & 113 & $21 / 06 / 2008$ & $15 / 06 / 2009$ & 359 & 359 & 7 & 177 \\
\hline 9518 & DST & 60 & 104 & $21 / 06 / 2008$ & 09/06/2009 & 353 & 353 & 57 & 248 \\
\hline 8808B & DST & 90 & 97 & $21 / 05 / 2009$ & $14 / 06 / 2010$ & 389 & 271 & 117 & 173 \\
\hline 34251 & PSAT & 15 & 114 & $11 / 07 / 2009$ & $11 / 01 / 2010$ & 184 & 184 & 47 & 59 \\
\hline 34256 & PSAT & 15 & 112 & $23 / 06 / 2007$ & $22 / 07 / 2007$ & 29 & 29 & 2 & 75 \\
\hline 34260 & PSAT & 15 & 92 & $12 / 06 / 2007$ & $26 / 06 / 2007$ & 14 & 14 & 25 & 161 \\
\hline 64487 & PSAT & 4 & 111 & $20 / 10 / 2009$ & $20 / 11 / 2009$ & 31 & 31 & 62 & 197 \\
\hline 83721 & PSAT & 60 & 148 & $23 / 05 / 2008$ & $20 / 05 / 2009$ & 362 & 362 & 99 & 210 \\
\hline
\end{tabular}


days of data for individual tags ranged from two weeks (Tag 34260, 14 days) to almost a full year (Tag 83721, 362 days). The discrepancy between a fish's time at-liberty and days of data of its corresponding tag resulted from the memory of the tag reaching its capacity. Nine of the tags provided data for summer months when the fish were presumably foraging and feeding in the nearshore waters. Six of the tags provided data from winter months when the fish presumably were spawning or migrating to offshore spawning locations.

Although some Atlantic halibut have been shown to undertake exceptionally long migrations $>2500 \mathrm{~km}$ (Stobo et al. 1988), all but one of the fish in this study had end locations within the GOM (Fig. 2) and most of the horizontal displacement distances were relatively small (mean $60.7 \mathrm{~km}$, range 2-211 km; Table 1). Some displacements were remarkably short, considering the length of time that the fish was at large. For example, a $113 \mathrm{~cm}$ fish (tag 9508) was recaptured only seven $\mathrm{km}$ from where it was tagged after being at liberty for 359 days. Another fish (tag 8833) was recaptured $17 \mathrm{~km}$ from where it was tagged 709 days earlier. Only one of the tagged fish (8823), the fish with the largest horizontal displacement (211 km), was recovered outside of the GOM, in relatively shallow coastal waters northeast of Browns Bank on the
Scotian Shelf (Fig. 2). These results corroborate findings from previous studies in which a majority of Atlantic halibut appear to demonstrate limited movements (Jensen and Wise 1961; Kohler 1964; Stobo et al. 1988; Kanwit 2007; Col and Legault 2009; den Heyer et al. 2012). These limited movements may result in a lack of intermingling of Atlantic halibut from Canadian and U.S. waters on spawning grounds, potentially limiting gene flow among these areas and resulting in the existence of different stocks of fish in geographically proximate areas.

None of the tagged Atlantic halibut occupied depths $>248 \mathrm{~m}$ (Fig. 3), implying that none left relatively shallow continental shelf waters for the deep basins of the GOM or the continental slope. From this observation, it is not possible to ascertain whether the tagged fish remained in the GOM while at liberty, as opposed to exiting the Gulf for the relatively shallow waters of the Scotian shelf, similar to one fish. However, it can be inferred that none occupied documented spawning grounds in the Northwest Atlantic in relatively deep water along the continental slope, where Atlantic halibut from the Scotian Shelf and Grand Banks have been shown to spawn (Armsworthy et al. 2014). This observation provides further evidence of a lack of intermingling of adult Atlantic halibut from the GOM and Canadian waters during the spawning season.

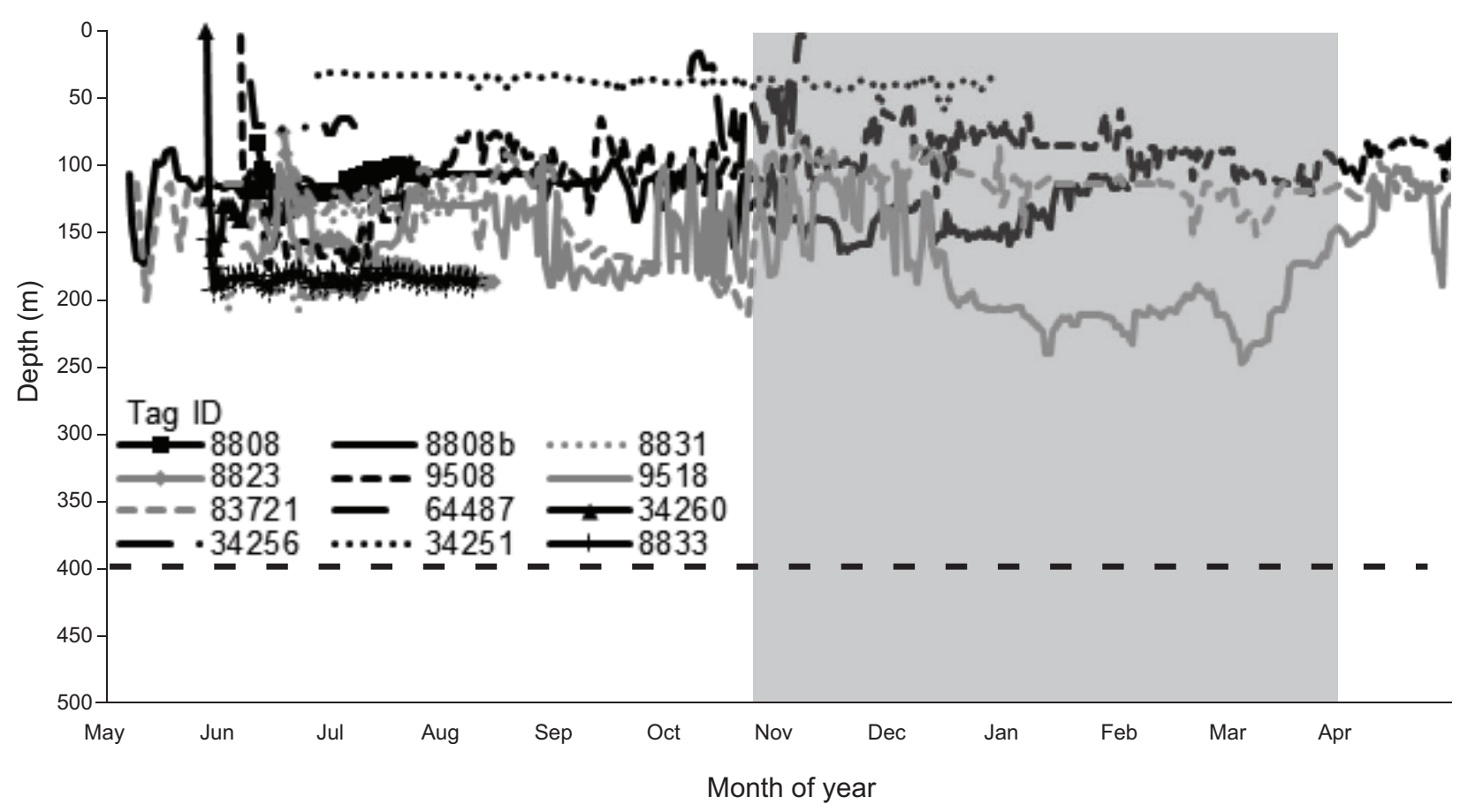

Fig. 3. Maximum daily depths occupied by 12 Atlantic halibut tagged with two types of electronic tags in the Gulf of Maine. The shaded area represents the purported spawning season of Atlantic halibut while the horizontal dashed line represents its minimum reported spawning depth. 
None of the tagged fish demonstrated any abrupt vertical movements termed 'spawning rises' (Seitz et al. 2005), at any depth or any time of year, that could be considered evidence of spawning activity. Although it is possible that the tagged fish were immature and therefore did not participate in spawning migrations and activity, this is unlikely based on the size of the tagged fish. One caveat is that the temporal resolution of some tags may prohibit identification of individual spawning rises, as the intervals between their depth readings were greater than the duration of spawning rises (Seitz et al. 2005). Furthermore, it is possible that frequent changes in occupied depths masked spawning rises.

Nevertheless, the lack of evidence of spawning behavior (migration to spawning areas, occupation of spawning depths and spawning activity) challenges some commonly-held assumptions about Atlantic halibut in the Northwest Atlantic, including 1) all Atlantic halibut spawn in deep water on the continental slope and 2) the majority of mature Atlantic halibut spawn annually. The apparent violation of these assumptions clearly requires reconsideration of Atlantic halibut biology and ecology in the Northwest Atlantic. First, it is possible that Atlantic halibut have a spawning behavior on the continental shelf without an abrupt rise that is not observable by electronic tags, which has not been documented previously. Second, it is possible that Atlantic halibut do not spawn annually, commonly referred to as skip-spawning. A recent reanalysis of electronic tag data from the closely related Pacific halibut proposed that $\sim 10 \%$ of mature fish do not participate in spawning migrations and of those that do, $10-15 \%$ may not actively spawn (Loher and Seitz 2008). It is possible that Atlantic halibut may have equal or even higher percentages of skip-spawning mature adults. A review of Kohler's (1967) size-at-maturity survey of Atlantic halibut determined that, of the largest $(>91 \mathrm{~cm})$ females surveyed $(n=26)$, only $50 \%$ were reproductively active (Burton 1999).

The observations in this study, taken together, suggest that adult Atlantic halibut that feed in the GOM during the summer may not commonly intermingle with fish from elsewhere in the Northwest Atlantic, potentially limiting gene flow of this species among geographically proximate regions. This observation provides further evidence that Atlantic halibut in Canadian and U.S. waters are not composed of a large, interbreeding population, as previously assumed (Stobo et al. 1988) and corroborates recent research suggesting that finer-scale stock structure exists for Atlantic halibut (Shakell et al. 2016). This fine scale stock structure may explain the disparity in abundance between U.S. and Canadian Atlantic halibut, and shed light on why the U.S. Atlantic halibut fishery has not recovered since its collapse (Shakell et al. 2016). Similar examples of relatively isolated spawning components of adult fish have been proposed for Atlantic halibut in a Norwegian fjord (Seitz et al. 2014) and Pacific halibut in the Aleutian Islands (Seitz et al. 2011). Although this study was small in both sample size and geographic scope, it adds to the body of knowledge about Atlantic halibut and provides direction for future research. Given the precarious status of Atlantic halibut stocks in U.S waters of the Northwest Atlantic, a better understanding of the species' stock identity and reproductive characteristics in different parts of this species' range could, one day, contribute to sound international management policies that facilitate a stock recovery that has eluded fisheries scientists and managers for almost a century and a half.

\section{Acknowledgments}

Funding for this project was provided by the National Marine Fisheries Service Northeast Cooperative Research Program through an award to the Maine Department of Marine Resources. We would like to thank the halibut fishermen, the staff at the Maine Department of Marine Resources Boothbay Laboratory, the field technicians and Chris Bartlett at Maine Sea Grant, all of whom made this project possible.

\section{References}

ARMSWORTHY, S. L., M. K. TRZCINSKI, and S. E. CAMPANA. 2014. Movements, environmental associations, and presumed spawning locations of Atlantic halibut (Hippoglossus hippoglossus) in the northwest Atlantic determined using archival satellite pop-up tags. Mar. Biol., 161(3): 645-656. DOI: 10.1007/s00227-013-2367-5

BIGELOW, H. B., and W. C. SCHROEDER. 1953. Fishes of the Gulf of Maine. Fish. Bull., 74, 577p.

BOWERING, W. R. 1986. The distribution, age, growth and sexual maturity of Atlantic halibut (Hippoglossus hippoglossus) in the Newfoundland and Labrador area of the Northwest Atlantic. Can. Tech. Rep. Fish. Aquat. Sci., 1432: iv $+34 \mathrm{p}$.

BURTON, M. P. M. 1999. Notes on potential errors in estimating spawning stock biomass: determining the effects of skipped spawning in female iteroparous fishes. J. Northw. Atl. Fish. Sci., 25: 205-213. DOI: 10.2960/J.v25.a18

COL, L. A., and C. M. LEGAULT. 2009. The 2008 assessment of Atlantic Halibut in the Gulf of Maine-Georges Bank region. U.S. Dept. Commer., Northeast Fish. Sci. Cent. Ref. Doc., 09-08; 39 p. http://nefsc.noaa.gov/publications/crd/ crd0908/crd0908.pdf. Accessed 22 June 2016.

DEN HEYER, C. E, A. ARMSWORTHY, S.WILSON, G. WILSON, L. BAJONA, S. BOND, AND M. K. TRZCINSKI. 2012. Atlantic halibut all-sizes tagging program summary report for 2006 to 2011. Can. Tech. Rep. 
Fish. Aquat. Sci. 2992: vii+34 p.

DEVOLD, F. 1938. The North Atlantic halibut and net fishing. Report on Norwegian fishery and marine investigations. Fiskeridir. Skr. Ser. Havunders., 5(6): 1-47.

GODØ, O. R., and T. HAUG. 1988. Tagging and recapture of Atlantic halibut (Hippoglossus hippoglossus L.) on the continental shelves off eastern Canada, and off western and eastern Greenland. J. Northw. Atl. Fish. Sci., 8: 25-31.

GRASSO, G. M. 2008. What appeared limitless plenty: the rise and fall of the nineteenth-century Atlantic halibut fishery. Environ. Hist., 13: 66-91. DOI: 10.1093/envhis/13.1.66

HAUG, T. 1990. Biology of the Atlantic halibut, Hippoglossus hippoglossus (L., 1758). Adv. Mar. Biol., 26: 1-70. DOI: 10.1016/S0065-2881(08)60198-4

HAUSER, L., AND G. R. CARVALHO. 2008. Paradigm shifts in marine fisheries genetics: ugly hypotheses slain by beautiful facts. Fish Fish., 9: 333-362. DOI: 10.1111/j.14672979.2008.00299.x

JENSEN, A. C., and J. P. WISE. 1961. Movement of tagged halibut off New England - II. T. Am. Fish. Soc., 90: 489-490. DOI: 10.1577/1548-8659(1961)90[489:MOTH $\mathrm{ON}] 2.0 . \mathrm{CO} ; 2$

KANWIT, J. K. 2007. Tagging results from the 2000-2004 federal experimental fishery for Atlantic Halibut (Hippoglossus hippoglossus) in the eastern Gulf of Maine. J. Northw. Atl. Fish. Sci., 38: 37-42. DOI:10.2960/J.v38.m594

KEATING, K. A. 1995. Mitigating elevation-induced errors in satellite telemetry locations. J. Wildl. Manag., 59: 801-808. DOI: $10.2307 / 3801960$

KOHLER, A. C. 1964. Movements of halibut on the Nova Scotian and Grand Banks. J. Fish. Res. Board Can., 21: 837-840. DOI: 10.1139/f64-073

1967. Size at maturity, spawning season. and food of Atlantic halibut. J. Fish. Res. Board Can., 24: 53-66. DOI: 10.1139/f67-006

LOHER, T. L., and A. C. SEITZ. 2008. Characterization of active spawning season and depth for eastern Pacific halibut (Hippoglossus stenolepis), and evidence of probable skipped spawning. J. Northw. Atl. Fish. Sci., 41: 23-36. DOI: $10.2960 /$ J.v41.m617

MCCRACKEN, F. D. 1958. On the biology and fishery of the Canadian Atlantic halibut Hippoglossus hippoglossus L. J. Fish. Res. Board Can., 15: 1269-1311. DOI: 10.1139/ f58-070

NATIONAL MARINE FISHERIES SERVICE (NMFS). 2009. Species of concern Atlantic halibut Hippoglossus hippoglossus. http://www.nmfs.noaa.gov/pr/pdfs/species/ atlantichalibut_detailed.pdf. Accessed 22 June 2016.

NEILSON, J. B., A. KEARNEY, P. PERLEY, and H. SAMPSON. 1993. Reproductive biology of Atlantic halibut (Hippoglossus hippoglossus) in Canadian waters. Can.
J. Fish. Aquat. Sci., 50: 551-563. DOI: 10.1139/f93-064

NORTHEAST FISHERIES SCIENCE CENTER (NEFSC). 2012. Assessment or data updates of 13 Northeast groundfish stocks through 2010. U.S. Dept. Commer., Northeast Fish. Sci. Cent. Ref. Doc., 12-06; 789 p. http:// nefsc.noaa.gov/publications/crd/crd1206/1206.pdf. Accessed 22 June 2016.

REID, D. P., S. PONGSOMBOON, T. JACKSON, C. MCGOWAN, C. MURPHY, D. MARTIN-ROBICHAUD, and M. REITH. 2005. Microsatellite analysis indicates an absence of population structure among Hippoglossus hippoglossus in the northwest Atlantic. J. Fish Biol., 67: 570-576. DOI: 10.1111/j.0022-1112.2005.00733.x

SEITZ, A. C., B. L. NORCROSS, D. WILSON, and J. L. NIELSEN. 2005. Identifying spawning behavior in Pacific halibut, Hippoglossus stenolepis, using electronic tags. Environ. Biol. Fishes, 73: 445-451. DOI: 10.1007/s10641005-3216-2

SEITZ, A. C., T. LOHER, B. L. NORCROSS, and J. L. NIELSEN. 2011. Dispersal and behavior of Pacific halibut Hippoglossus stenolepis in the Bering Sea and Aleutian Islands region. Aquat. Biol., 12: 225-239. DOI: 10.3354/ ab00333

SEITZ, A. C., K. MICHALSEN, J. L. NIELSEN, and M. D. EVANS. 2014. Evidence of fjord spawning by southern Norwegian Atlantic halibut (Hippoglossus hippoglossus). ICESJ. Mar. Sci., 71(5): 1142-1147. DOI: 10.1093/icesjms/ fst 227

SHACKELL, N. L., K. T. FRANK, J. A. NYE, and C. E. DEN HEYER. 2016. A transboundary dilemma: dichotomous designations of Atlantic halibut status in the Northwest Atlantic. ICES J. Mar. Sci. 73(7): 1798-1805. DOI: 10.1093/icesjms/fsw042

SIGOURNEY, D. B., M. R. ROSS, J. BRODZIAK, and J. BURNETT. 2006. Length at age, sexual maturity and distribution of Atlantic halibut, Hippoglossus hippoglossus L., off the Northeast USA. J. Northw. Atl. Fish. Sci., 36: 81-90. DOI: 10.2960/J.v36.m574

STOBO, W. T., J. D. NEILSON, and P. G. SIMPSON. 1988. Movements of Atlantic halibut (Hippoglossus hippoglossus) in the Canadian North Atlantic: inference regarding life history. Can. J. Fish. Aquat. Sci., 45: 484-491. DOI: 10.1139/f88-058

TRZCINSKI, M. K., AND W. D. BOWEN. 2016. The recovery of Atlantic halibut: a large, long-lived, and exploited marine predator. ICES J. Mar. Sci. 73(4): 1104-1114. DOI: 10.1093/icesjms/fsv266

VAN DER MEEREN, T., G. DAHLE, and O. I. PAULSEN. 2013. A rare observation of Atlantic halibut larvae (Hippoglossus hippoglossus) in Skjerstadfjorden, North Norway. Mar. Biodivers. Rec., 6: 1-4. DOI: 10.1017/S1755267213000511 